\title{
Effects of clay-mineral type and content on the hydraulic conductivity of bentonite-sand mixtures made of Kunigel bentonite from Japan
}

\author{
MASANORI KOHNO ${ }^{1, *}$, YOSHITAKA NARA ${ }^{2}$, MASAJI KATO $^{3}$ AND \\ TSUYOSHI NISHIMURA ${ }^{1}$ \\ Tottori University, Tottori 680-8552, Japan \\ Kyoto University, Kyoto 615-8540, Japan \\ ${ }^{3}$ Hokkaido University, Hokkaido 060-8628, Japan
}

(Received 29 November 2017; revised 16 June 2018; Accepted Manuscript published online: 17 December 2018; Version of Record published online: 1 February 2019; Guest Associate Editor: R. Dohrmann)

\begin{abstract}
Clay-mineral type and content, bulk mineralogical composition and alteration of bentonite are very important factors for the ultra-long-term stabilization of barriers and backfills in radioactive waste disposal. This study investigates the effects of clay-mineral type and content on the swelling characteristics and permeability of bentonite-sand mixtures with clay minerals using onedimensional swelling-pressure and constant-pressure permeability tests. The hydraulic conductivity of bentonite-sand-clay mineral mixtures increased with increasing content of non-swelling alteration products of montmorillonite. Furthermore, hydraulic conductivity was comparable to that determined with the Kozeny-Carman equation for a specific surface area, suggesting that hydraulic conductivity may be estimated based on the abundance of expected alteration products of montmorillonite. This study provides a basis for evaluation of the hydraulic conductivity of bentonite-sand mixtures with known quantities of expected alteration products of montmorillonite.
\end{abstract}

KEYWORDS: clay mineral, swelling pressure, hydraulic conductivity, bentonite-sand mixtures, alteration, specific surface area.

Engineered barriers and backfill for the geological disposal of radioactive waste require ultra-long-term

This paper was presented during the "7th International Conference on Clays in Natural and Engineered Barriers for Radioactive Waste Confinement', September 2017. *E-mail:kohnom@tottori-u.ac.jp https://doi.org/10.1180/clm.2018.52

This is an Open Access article, distributed under the terms of the Creative Commons Attribution licence (http:// creativecommons. org/licenses/by/4.0/), which permits unrestricted re-use, distribution, and reproduction in any medium, provided the original work is properly cited stabilization. The use of compacted sodium-type bentonite-sand mixtures for this purpose has received increased attention. Previous work has studied the swelling characteristics, permeability and self-sealing capacity of bentonite and bentonite-sand mixtures (e.g. Komine \& Ogata, 1994, 1999a; Mollins et al., 1996; Cho et al., 1999; Sivapullaiah et al., 2000; Shirazi, 2010; Suzuki et al., 2013). Pusch (1999) studied the swelling pressure and hydraulic conductivity of various clay materials such as kaolinite, smectite and palygorskite. Sellin \& Leupin (2013) have reviewed most of the results from over the past 35 years on the safety-relevant properties of clays used as engineered barriers for the geological disposal of 
radioactive waste. However, few quantitative data on the effects of clay mineral types, contents and alterations on the swelling characteristics and permeability of bentonite-sand mixtures have been reported to date. Furthermore, many researchers (e.g. Nakayama et al., 2004; Yamaguchi et al., 2007; Cuisinier et al., 2008; Chen et al., 2016) have studied the swelling characteristics and permeability of altered bentonite using alkaline solutions and various approaches. Yamaguchi et al. (2013) reported an increase in the hydraulic conductivity of bentonite-sand mixtures after alteration by alkaline fluids. However, the swelling characteristics and permeability of bentonite-sand mixtures containing kaolinite and chlorite as alteration minerals have yet to be investigated. In the ultra-long-term use of bentonite-sand mixtures for geological disposal of radioactive waste, it is assumed that montmorillonite will be at least partly altered to illite or chlorite, and feldspar to kaolinite (e.g. Inoue et al., 1987; Japan Nuclear Cycle Development Institute, 2000; Nakayama et al., 2004; Yokoyama et al., 2006; Savage et al., 2007; Yokoyama \& Nakamura, 2010). These alterations may deteriorate the properties of bentonite-sand mixtures. Thus, the swelling characteristics and permeability of bentonite appear to be affected by alteration. The rate of alteration of bentonite-sand mixtures is slow. Several mathematical models have been developed to predict the ultra-long-term effects of alteration on the properties of bentonite-sand mixtures (e.g. Ishikawa et al., 1994; Savage et al., 2002; Ishii et al., 2013). However, very few experimental data on the modification of hydraulic conductivity have been reported.

Hydrothermal alteration by volcanic-hydrothermal systems and weathering over geological time and historical periods have occurred widely throughout the Pacific Rim region. As a result of these processes, a wide variety of clay-rich sediments, bentonites and soils occur on the surface and in the crust of the Earth. The mineral composition of bentonite depends on the parent material and weathering environment. Bentonite is composed mainly of montmorillonite mixed with other clay minerals (e.g. illite, kaolinite, chlorite) and non-clay minerals (e.g. quartz, feldspars, carbonates, pyrite). Furthermore, the physical and mechanical properties of clay minerals vary, as shown by their structures.

Thus, clay-mineral type and content, crystalchemical composition and assemblage and the expected alteration products of bentonite are important factors for the ultra-long-term stabilization of barriers and backfill in radioactive waste disposal. This study investigated the effects of clay-mineral types and contents on the swelling characteristics and permeability of bentonite-sand mixtures in laboratory experiments. Bentonite-sand-clay mineral mixtures might be affected by the alteration of bentonite via changes in the clay-mineral content. To clarify the effect of clay-mineral content, the bentonite-sand-clay mineral mixtures were subjected to one-dimensional swelling-pressure and constant-pressure permeability tests.

\section{METHODS}

\section{Materials}

One-dimensional swelling-pressure and constantpressure permeability tests with samples containing one clay mineral were carried out to clarify the influence of clay mineralogy on swelling pressure and hydraulic conductivity. The clay minerals used were kaolinite, $10 \AA$ halloysite, talc, mica and chlorite. The clay-mineral samples were collected primarily from ancient hydrothermal fields. The samples passed through a $75 \mu \mathrm{m}$ mesh sieve. Next, the kaolinite, mica and chlorite were mixed with bentonite and sand to form bentonite-sand-clay mineral mixtures for onedimensional swelling-pressure and constant-pressure permeability tests. The bentonite and silica sand used in this study were Kunigel-V1 collected in Tsukinuno Mine, Japan, and Mikawa no. 6 silica sand, respectively. Kunigel-V1 is composed of montmorillonite (46-49\%), quartz (29-38\%), feldspars $(2.7-5.5 \%)$, calcite (2.1-2.6\%), dolomite (2.0-2.8\%), zeolites (3.0$3.5 \%$ ) and pyrite $(0.5-0.7 \%)$ (Ito et al., 1993; Japan Nuclear Cycle Development Institute, 2000). Mikawa no. 6 silica sand is composed mainly of quartz. In order to avoid confusion with montmorillonite (clay mineral), we use the term 'clay mineral sample' for kaolinite, $10 \AA$ halloysite, talc, mica and chlorite. In addition, the kaolinite, mica and chlorite used for the bentonitesand-clay mineral mixtures are referred to as "nonswelling alteration products' (NSAPs) (Fig. 1). Table 1 and Fig. 1 show the particle densities of the samples and proportions of bentonite, silica sand and clay mineral samples. The particle densities $\left(\rho_{\mathrm{S}}\right)$ of bentonite-sand mixtures were calculated from equation 1 :

$$
\rho_{\mathrm{s}}=\frac{m}{\frac{m_{\mathrm{B}}}{\rho_{\mathrm{B}}}+\frac{m_{\mathrm{N}}}{\rho_{\mathrm{N}}}+\frac{m_{\mathrm{S}}}{\rho_{\mathrm{S}}}}
$$

where $m$ is the mass, $\rho$ is the particle density and the subscripts $\mathrm{B}, \mathrm{N}$ and $\mathrm{S}$ represent bentonite, mixed NSAPs and silicate sand, respectively. 


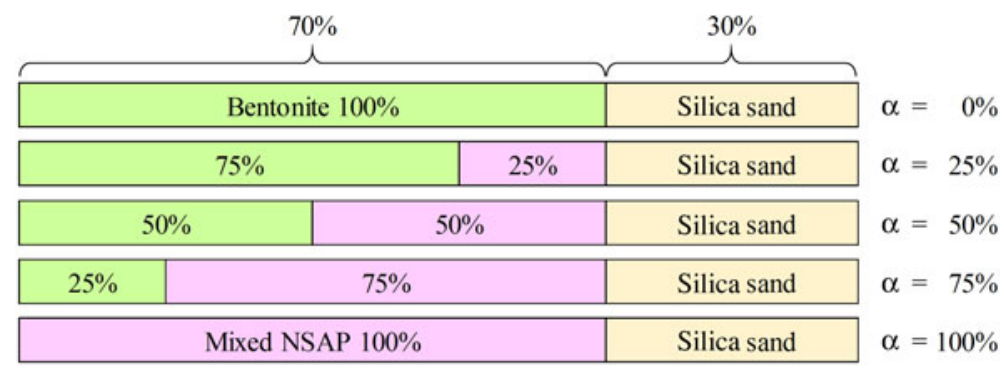

FIG. 1. Proportions of components in bentonite-sand-clay mineral mixtures. Mixed NSAPs were kaolinite, mica and chlorite.

The ratio of bentonite and mixed NSAPs to sand was $7: 3$ in dry mass. The materials were dried at $40 \pm 3^{\circ} \mathrm{C}$ in an electric oven to achieve a constant mass and to avoid structural collapse caused by dehydration of $10 \AA$ halloysite and montmorillonite. The mixed NSAP replacement ratio to bentonite $(\alpha)$, defined as the mass of the clay-mineral sample divided by the mass of the bentonite and clay mineral sample, ranged from $0 \%$ to $100 \%$ at $25 \%$ intervals (Fig. 1). Three materials (bentonite, mixed NSAPs and silica sand) were mixed in a container. Bentonite and the clay mineral sample were identified by X-ray diffraction (XRD) traces of untreated powder samples (Fig. 2). The XRD was performed with a Rigaku Ultima IV diffractometer (40 kV, $20 \mathrm{~mA}, 0.03 \mathrm{~s} / \mathrm{step})$ using $\mathrm{Cu}-K \alpha$ radiation, a $0.15 \mathrm{~mm}$ receiving slit, a $0.5^{\circ}$ divergence slit and a $2^{\circ}$ scattering slit. The kaolinite sample is composed mainly of kaolinite with traces of quartz (Fig. 2c). The talc sample consists mainly of talc and traces of chlorite (Fig. 2e). The chlorite sample is composed mainly of chlorite with minor quartz, feldspars calcite and sepiolite (Fig. 2g). The specific surface areas of the clay-mineral powder samples and silicate sand were

TABle 1. Particle densities of samples.

\begin{tabular}{lc}
\hline Samples & Particle density $\left(\mathrm{g} / \mathrm{cm}^{3}\right)$ \\
\hline Bentonite & $2.7^{a}$ \\
Silicate sand & 2.663 \\
Clay mineral samples & \\
$\quad$ Kaolinite & 2.577 \\
$10 \AA$ halloysite & 2.736 \\
Talc & 2.786 \\
Mica & 2.904 \\
Chlorite & 2.841 \\
\end{tabular}

${ }^{a}$ Japan Nuclear Cycle Development Institute (2000). determined by $\mathrm{N}_{2}$ adsorption with the BrunauerEmmett-Teller (BET) method after degassing at $200^{\circ} \mathrm{C}$ for $1 \mathrm{~h}$. The specific surface areas of the samples are listed in Table 2.

\section{Sample preparation and test procedure}

The specimens used for one-dimensional swellingpressure and constant-pressure permeability tests were $50 \mathrm{~mm}$ in diameter and $10 \mathrm{~mm}$ in height. The dried clay mineral and bentonite-sand mixtures were compacted statically to a dry unit mass of $1.4 \mathrm{mg} / \mathrm{m}^{3}$. The compacted specimens were produced using an apparatus composed of a cylindrical mould, pistons and an oil-pressure jack. The tests were performed at $22 \pm 1^{\circ} \mathrm{C}$ in a temperature-controlled room.

Figure 3 shows the experimental configuration of the one-dimensional swelling-pressure test. The testing system consisted of an elevating-load machine, cylindrical mould (acrylic resin ring), base plate, loading plate, load cell, porous stone, water-immersing container and displacement transducer. The test was performed at constant volume. A specimen was placed in the cylindrical mould with a base plate, the assembly was inserted into the water-immersing container and the container was filled with distilled water. A $0.003 \mathrm{kN}$ load was then applied to ensure that the height of the specimen did not change, and the axial swelling pressure was determined from the vertical force applied at that time. A displacement transducer was used to measure the displacement of the specimen throughout the test. The maximum value of displacement was $0.01 \mathrm{~mm}$. The swelling pressure is given by equation 2:

$$
P_{\mathrm{s}}=\frac{F}{A}
$$

where $P_{\mathrm{s}}$ is the swelling pressure, $F$ is the vertical force and $A$ is the cross-sectional area of the specimen. A 
(a)

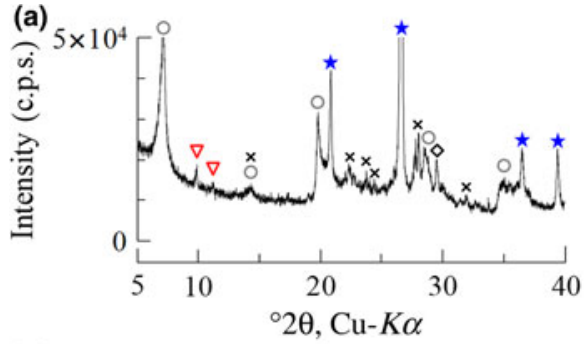

(c)

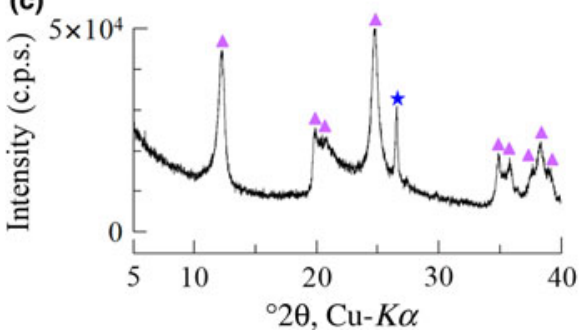

(e)

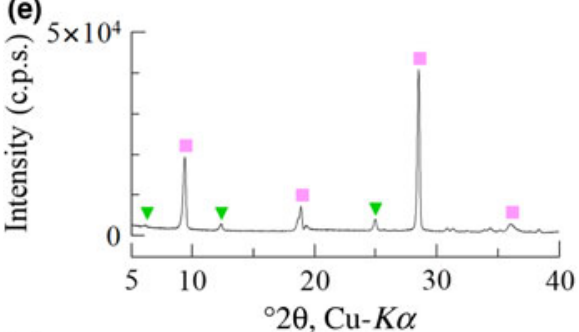

(g)

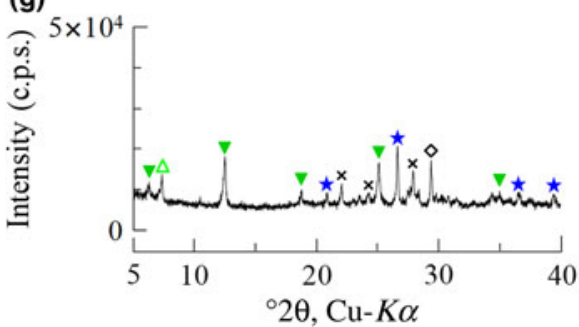

(b)

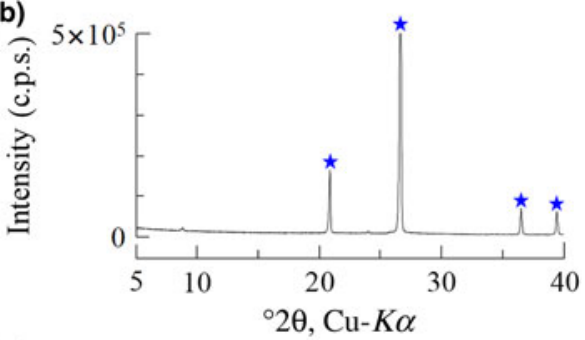

(d)

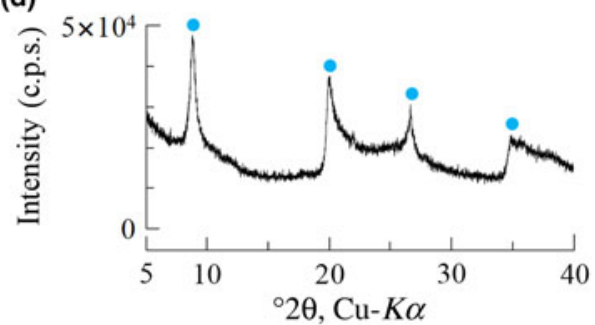

(f)

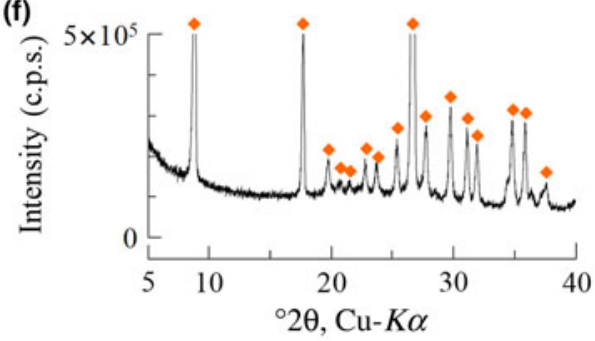

$\diamond$ Calcite

$\nabla$ Clinoptilolite

$\checkmark$ Chlorite

$\times$ Feldspars

- $10 \AA$ halloysite

- Mica

$\star$ Quartz

$=$ Talc $\triangle$ Kaolinite

- Montmorillonite

$\triangle$ Sepiolite

FIG. 2. Random XRD traces of (a) bentonite, (b) silica sand and clay-mineral powders: (c) kaolinite, (d) $10 \AA$ halloysite, (e) talc, (f) mica and (g) chlorite. c.p.s. $=$ counts per second.

data logger was used to measure vertical force at $1 \mathrm{~s}$ intervals. The test was conducted for at least $72 \mathrm{~h}$, after which measurements were taken until the swelling pressure had been constant for $24 \mathrm{~h}$.

Figure 4 shows the experimental configuration of the constant-pressure permeability test. The testing system consisted of a compressor, pressure water tank, pressure regulator, pressure gauge, water pipe, permeability cylindrical mould (stainless steel), filters (paper and porous stone), $\mathrm{O}$ rubber ring and electronic balance. The pipe and cylinder were made of stainless steel. The electronic balance $(0.1 \mathrm{mg}$ accuracy) was used to measure the amount of water discharge, with consideration of evaporation. The runoff volume was measured at $1 \mathrm{~min}$ intervals, and the data were transmitted from the balance to a personal computer. Each specimen was saturated using a water-filled decompression container. The swelling pressure of the clay mineral samples attained equilibrium at $\sim 2$ days (Fig. 5). Therefore, the water-immersion times were determined to be 4 days for the clay-mineral samples and 7 days for bentonite. The water-immersion time for 
TABLE 2. Specific surface areas of clay-mineral powder samples and silica sand, measured according to the BET method.

\begin{tabular}{lc}
\hline Samples & Specific surface area $\left(\mathrm{m}^{2} / \mathrm{g}\right)$ \\
\hline Kaolinite & 40.42 \\
$10 \AA$ halloysite & $61^{a}$ \\
Talc & $5.39^{b}$ \\
Mica & 4.85 \\
Chlorite & 5.20 \\
Silica sand & 0.09 \\
\hline
\end{tabular}

${ }^{a}$ The Clay Science Society of Japan (2009).

${ }^{b}$ Holland \& Murtagh (2000).

bentonite corresponds to at least the duration of the one-dimensional swelling-pressure tests. The minimum degree of saturation of specimens was $98.9 \%$. Therefore, the specimens used were considered to be water-saturated. Distilled water was passed through the specimen at constant water pressure using a compressor and pressure water tank. Measurements were taken for $\geq 24 \mathrm{~h}$ after the first confirmation of water runoff. The water pressure was kept lower in the constant-pressure permeability test than in the swelling-pressure test to avoid consolidation or water path (Table 3). As an exception, the water pressure of the chlorite sample and chlorite-sand mixtures $\left(\alpha=100 \%, P_{\mathrm{s}}<0.002 \mathrm{MPa}\right)$ was $0.002 \mathrm{MPa}$. Consolidation or water path of these specimens was not observed after the test. The hydraulic conductivity of clay mineral samples and bentonite-sand mineral mixtures was calculated from Darcy's law (equation 3):

$$
k=\frac{Q L}{h A t}
$$

where $k$ is the hydraulic conductivity, $Q$ is the runoff volume, $L$ is the height of the specimen, $h$ is the difference in water level, $A$ is the cross-sectional area of the specimen and $t$ is time. $h$ was calculated according to the pressure in the pressure water tank (e.g. at water pressure $0.1 \mathrm{MPa}, h$ is $1020.4 \mathrm{~cm}$ ). The water pressure was controlled using the pressure regulator and the pressure gauge. The accuracy was to $0.002 \mathrm{MPa}$. The hydraulic conductivity of bentonite-sand mixtures depends slightly on the hydraulic gradient $i(=h / L)$ (Nakamura et al., 2011). In this study, the hydraulic gradient $(i=20.4-3571.4)$ did not affect hydraulic conductivity.

\section{RESULTS AND DISCUSSION}

Swelling-pressure and hydraulic conductivity measurements were performed with mixed NSAPs and bentonite (Figs 5, 6) and admixtures thereof (Fig. 7). The reproducibility of the one-dimensional swelling-pressure and constant-pressure permeability tests was assessed in triplicate experiments. Sample data in Fig. 5 represent the average of at least three measurements under the same conditions. Figure 6 shows the error bars (range of maximum and minimum values) of the sample data. The standard deviation of the swelling pressure was $0.008 \mathrm{MPa}$. The differences between the maximum and minimum values of the hydraulic conductivity of samples were less than one order of magnitude. Therefore, the variation in the swelling pressure and hydraulic conductivity of the samples was very small.

\section{Swelling pressure and hydraulic conductivity of the clay-mineral samples and bentonite}

The swelling pressures of five clay-mineral samples and bentonite are shown in Fig. 5. The average swelling pressure was highest for bentonite $\left(P_{\mathrm{s}}=\right.$ $0.48 \mathrm{MPa})$, followed by $10 \AA$ halloysite $\left(P_{\mathrm{s}}=\right.$ $0.24 \mathrm{MPa})$ and kaolinite $\left(P_{\mathrm{s}}=0.17 \mathrm{MPa}\right)$. In contrast, values for talc and mica were low $\left(P_{\mathrm{s}}=0.01\right.$ and $0.02 \mathrm{MPa}$, respectively), and that for chlorite was $<0.002 \mathrm{MPa}$. The bentonite required a longer time than the clay mineral samples to reach equilibrium swelling pressure. However, because bentonite has low permeability, a longer time was required for the water to reach all parts of the specimen. The swelling pressures of the clay mineral samples differed according to the claymineral type. In particular, the swelling pressures of $10 \AA$ halloysite and kaolinite were greater than those of the other clay-mineral samples. Because the specific surface areas of $10 \AA$ halloysite and kaolinite were also larger than those of the other clay-mineral samples (Table 2), the adsorbed water owing to surface tension increased. Thus, the pore-water pressure and the swelling pressure of halloysite and kaolinite increased.

The relationships between swelling pressure and hydraulic conductivity for the five clay-mineral samples and bentonite are shown in Fig. 6 and Table 4. Hydraulic conductivity was lowest for bentonite (average of $k=5.3 \times 10^{-13} \mathrm{~m} / \mathrm{s}$ ), followed by kaolinite and $10 \AA$ halloysite $\left(10^{-10} \mathrm{~m} / \mathrm{s}\right)$ and mica, talc and chlorite $\left(10^{-8} \mathrm{~m} / \mathrm{s}\right)$. The hydraulic conductivity of bentonite in this study was comparable to that reported in previous studies under similar conditions $\left(4.8 \times 10^{-12} \mathrm{~m} / \mathrm{s}\right)($ Suzuki et al., 1992). The hydraulic 


\section{Temperature-controlled room}

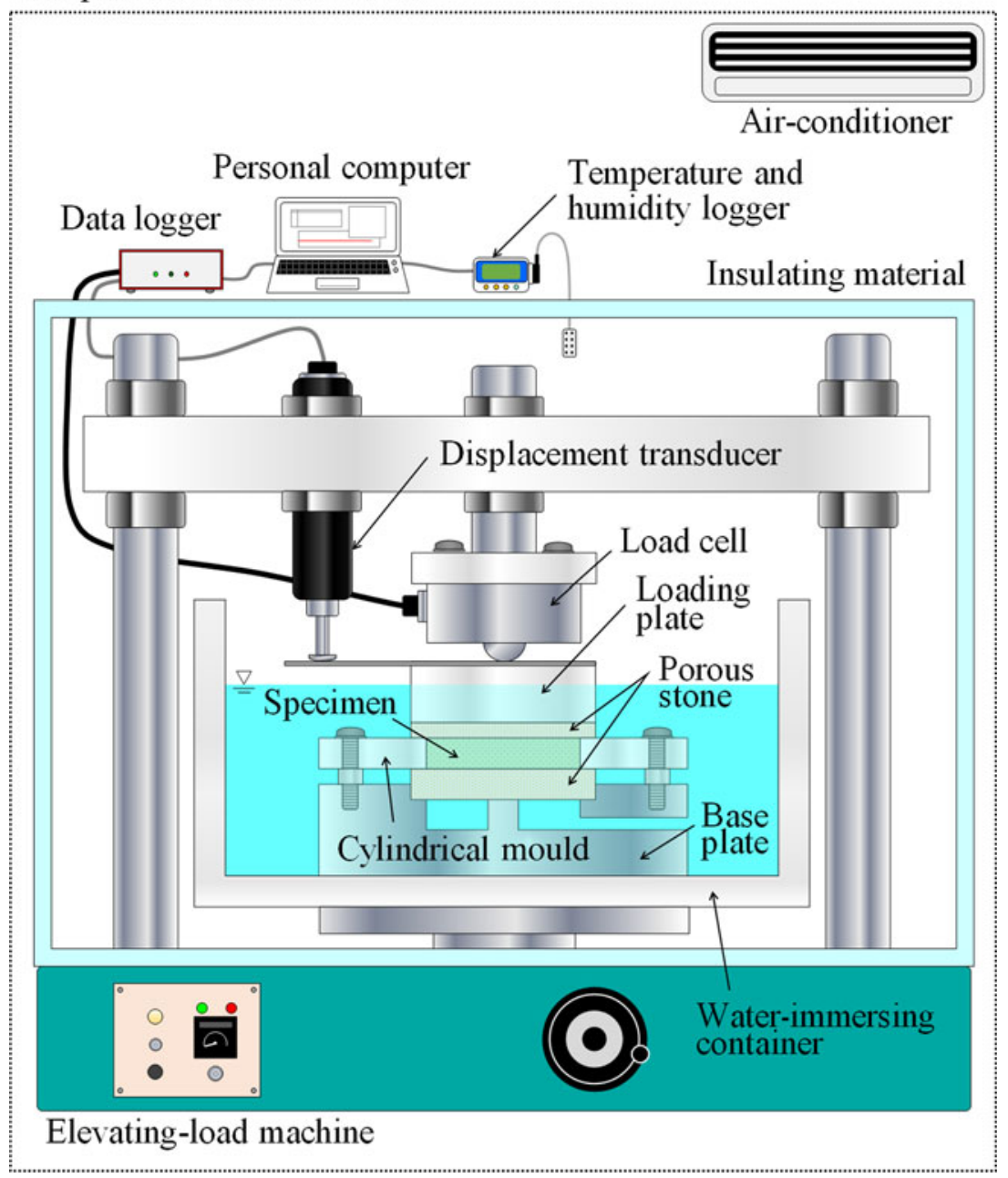

FIG. 3. Schematic diagram of the experimental configuration for the one-dimensional swelling-pressure test.

conductivity of the specimens decreased with increasing swelling pressure, and analysis revealed a strong correlation ( $\mathrm{R}=0.97$; Fig. 6$)$. The hydraulic conductivity of the clay-mineral samples varied according to the clay-mineral type. Interestingly, the swelling pressure $\left(P_{\mathrm{s}}\right)$, hydraulic conductivity $(k)$ and specific surface area $(S)$ of the kaolinite and halloysite (both with 1:1 layer structures) were similar, and the $P_{\mathrm{s}}, k$ and $S$ of talc (2:1 layer), mica (2:1 layer) and chlorite (2:1:1 layer) were comparable. The large specific surface area resulted in an increase in pore-water viscosity, which in turn led to low hydraulic conductivity (Achari et al., 1999). The relationship between the clay-mineral structures or the interlayer bonding force and hydraulic conductivity will be clarified in future studies. In particular, montmorillonite in bentonite has a 2:1 layer. Because it is a swelling clay mineral containing water and cations between layers, however, a significantly larger electric double layer is formed compared with those for mica or chlorite. It is suggested that the formation of an immobile water film in the electric double layer and physicochemical action (adsorption and flocculation) by the swelling clay mineral contributed significantly to the low hydraulic conductivity of bentonite (Achari et al., 1999; Mitchell \& Soga, 2005). The hydraulic conductivities of kaolinite, mica and chlorite, which might have formed during the alteration of bentonite under 
Temperature-controlled room

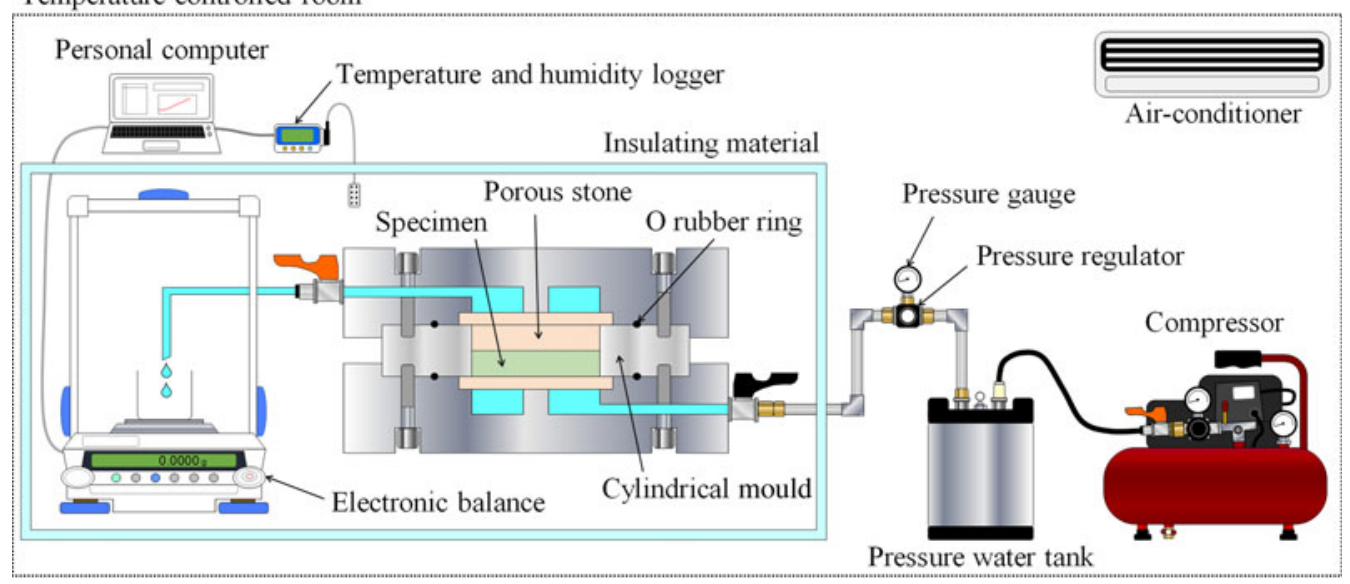

FIG. 4. Schematic diagram of the experimental configuration for the constant-pressure permeability test.

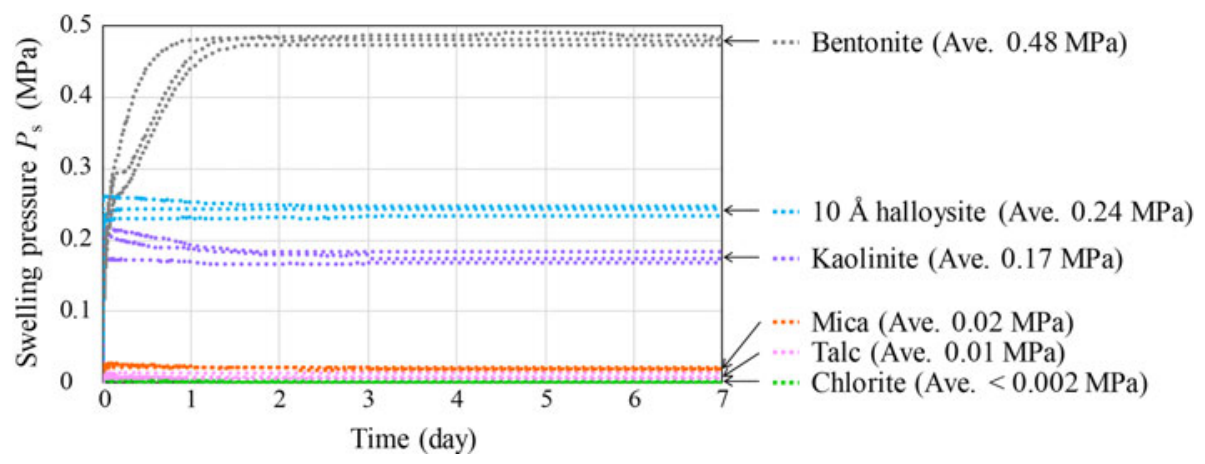

FIG. 5. One-dimensional swelling pressure of clay-mineral samples and bentonite (Kunigel V1).

repository conditions, and those of mica and chlorite were approximately three to five orders of magnitude greater than the hydraulic conductivity of bentonite. These experimental results suggest that an increase in non-swelling clay minerals due to alteration of bentonite increases hydraulic conductivity.

\section{Swelling pressure and hydraulic conductivity of bentonite-sand-clay mineral mixtures}

The relationship between the swelling pressure and hydraulic conductivity of the bentonite-sand-clay mineral mixtures is shown in Fig. 7. The swelling pressure of the bentonite-sand-clay mineral mixtures ranged from 0.00 to $0.25 \mathrm{MPa}$. The swelling pressure decreased with increasing replacement of bentonite by NSAPs, without major differences among the various types of NSAPs. The hydraulic conductivity of the bentonite-sand mixtures decreased with increasing swelling pressure, and analysis revealed a strong correlation $(\mathrm{R}=0.87)$.

The relationships between the mixed NSAP replacement ratio to bentonite and hydraulic conductivity of the bentonite-sand-clay mineral mixtures are shown in Fig. 8. The hydraulic conductivities of the kaolinitesand, mica-sand and chlorite-sand mixtures $(\alpha=$ $100 \% ; k=6.3 \times 10^{-10} \mathrm{~m} / \mathrm{s}, 3.6 \times 10^{-8} \mathrm{~m} / \mathrm{s}$ and $9.4 \times$ $10^{-8} \mathrm{~m} / \mathrm{s}$, respectively) were more than two to four orders of magnitude greater than that of the bentonitesand mixture $\left(\alpha=0 \%, k=1.4 \times 10^{-12} \mathrm{~m} / \mathrm{s}\right)$. The hydraulic conductivity of the bentonite-sand mixture $(\alpha=0 \%)$ was similar to that observed previously under the same test conditions $\left(1.0 \times 10^{-12} \mathrm{~m} / \mathrm{s}\right)$ (Suzuki et al., 1992). Compared with the hydraulic conductivity of the bentonite-sand mixtures $(\alpha=0 \%)$, that of the bentonite-sand-clay mineral mixtures did not 
TABLE 3. Swelling pressure $\left(P_{\mathrm{s}}\right)$ of specimens and water pressure $\left(P_{\mathrm{w}}\right)$ for the constant-pressure permeability test.

\begin{tabular}{lcc}
\hline $\begin{array}{l}\text { Specimen } \\
\text { Bentonite }\end{array}$ & $\begin{array}{l}P_{\mathrm{s}} \\
\text { Clay mineral samples }\end{array}$ & $\begin{array}{l}P_{\mathrm{w}} \\
(\mathrm{MPa})\end{array}$ \\
$\quad$ Kaolinite & 0.48 & 0.35 \\
$10 \AA$ halloysite & 0.17 & 0.16 \\
Talc & 0.24 & 0.22 \\
Mica & 0.01 & 0.01 \\
Chlorite & 0.02 & 0.02 \\
Bentonite-sand mixture $(\alpha=0 \%)$ & 0.002 & 0.002 \\
Bentonite-sand-clay mineral & & 0.24 \\
mixtures & & \\
Kaolinite mixture $(\alpha=25 \%)$ & 0.20 & 0.18 \\
$\quad(\alpha=50 \%)$ & 0.12 & 0.10 \\
$\quad(\alpha=75 \%)$ & 0.05 & 0.04 \\
$\quad(\alpha=100 \%)$ & 0.03 & 0.02 \\
Mica mixture $(\alpha=25 \%)$ & 0.19 & 0.16 \\
$\quad(\alpha=50 \%)$ & 0.11 & 0.10 \\
$\quad(\alpha=75 \%)$ & 0.05 & 0.04 \\
$\quad(\alpha=100 \%)$ & 0.01 & 0.01 \\
Chlorite mixture $(\alpha=25 \%)$ & 0.19 & 0.18 \\
$\quad(\alpha=50 \%)$ & 0.11 & 0.08 \\
$(\alpha=75 \%)$ & 0.04 & 0.02 \\
$(\alpha=100 \%)$ & $<0.002$ & 0.002 \\
& & \\
\hline & &
\end{tabular}

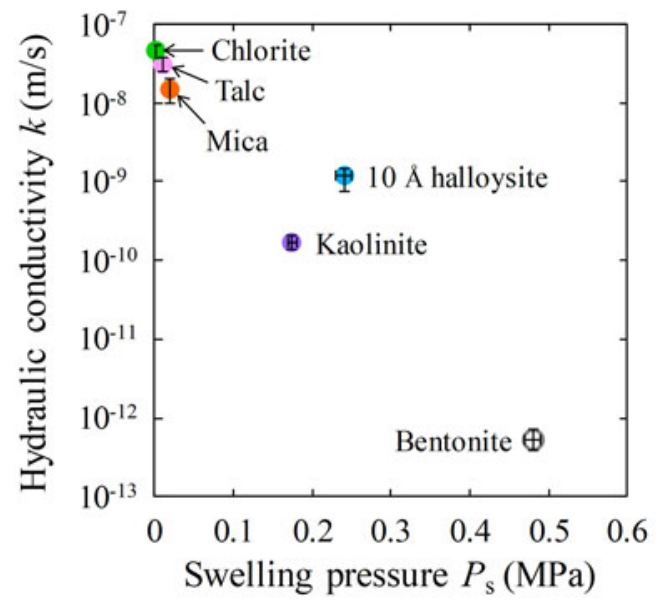

FIG. 6. Relationship between swelling pressure and hydraulic conductivity of clay-mineral samples and Kunigel V1.

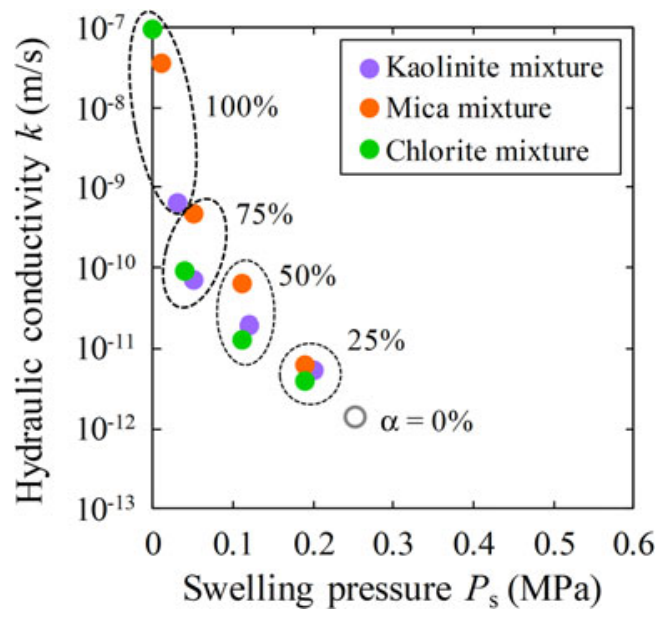

FIG. 7. Relationship between swelling pressure and hydraulic conductivity of bentonite-sand-clay mineral mixtures.

differ in magnitude for $\alpha=25 \%$. However, a difference of one order of magnitude was noted for $\alpha=50 \%$, and a difference of one to two orders of magnitude was observed for $\alpha=75 \%$.

The hydraulic conductivity of the bentonite-sandclay mineral mixtures increased with the mixed NSAP replacement ratio. For mixtures without bentonite (i.e. clay mineral-sand mixtures), hydraulic conductivity differed depending on the mixed NSAP mineral type, suggesting that an increase in clay minerals due to alteration leads to increased hydraulic conductivity. Conversely, the hydraulic conductivity of kaolinite, mica and chlorite $(\alpha=25 \%)$ was comparable, and was not affected by the mixed NSAP type. When a small

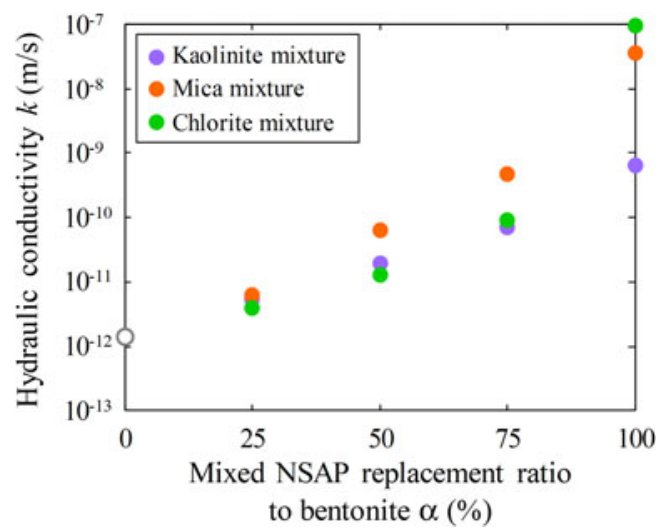

FIG. 8. Relationship between mixed NSAP replacement ratio to bentonite and hydraulic conductivity of bentonitesand-clay mineral mixtures. 
TABLE 4. Hydraulic conductivity $(k)$ of samples.

\begin{tabular}{ll}
\hline Samples & $k(\mathrm{~m} / \mathrm{s})$ \\
\hline Bentonite & $(5.3 \pm 1.5) \times 10^{-13}$ \\
Clay mineral samples & $(1.7 \pm 0.3) \times 10^{-10}$ \\
$\quad$ Kaolinite & $(1.2 \pm 0.3) \times 10^{-9}$ \\
$10 \AA$ halloysite & $(3.1 \pm 0.5) \times 10^{-8}$ \\
Talc & $(5.3 \pm 0.4) \times 10^{-8}$ \\
Mica & $(5.3 \pm 0.7) \times 10^{-8}$ \\
Chlorite & \\
\hline
\end{tabular}

amount of bentonite was added, the hydraulic conductivity was not affected considerably by the mixed NSAP type. In other words, hydraulic conductivity appears to be affected significantly by bentonite swelling. This swelling fills most voids when the bentonite content is large. However, as the mixed NSAP content increases, swelling pressure decreases and the filling of voids becomes difficult, resulting in increased hydraulic conductivity. Therefore, hydraulic conductivity may not be affected significantly by claymineral type when bentonite is present.

\section{Hydraulic conductivity of bentonite-sand-clay} mineral mixtures as determined by the KozenyCarman equation

Various parameters, such as the specific surface area and void ratio, change due to differences in the clay mineral content. Among models representing the hydraulic conductivity of the porous media, the Kozeny-Carman equation (equation 4) uses the specific surface area. As this equation incorporates macroparameters (i.e. void ratio) and microparameters (i.e. specific surface area), it is often used to evaluate the hydraulic conductivity of bentonite-sand mixtures (e.g. Ren et al., 2016; Kobayashi et al., 2017). The Kozeny-Carman equation (Kozeny, 1927; Carman, 1937) is:

$$
k_{\mathrm{KC}}=C \frac{\rho_{\mathrm{w}} g}{\eta} \cdot \frac{1}{S_{\mathrm{m}}^{2} \rho_{\mathrm{s}}^{2}} \cdot \frac{e^{3}}{1+e}
$$

where $k_{\mathrm{KC}}(\mathrm{m} / \mathrm{s})$ is hydraulic conductivity, $C$ is a dimensionless shape constant with an approximate value of $0.2, \rho_{\mathrm{w}}\left(=997.770 \mathrm{~kg} / \mathrm{m}^{3}\right)$ is the density of water at $22^{\circ} \mathrm{C}, g$ is gravitational acceleration $\left(=9.8 \mathrm{~m} / \mathrm{s}^{2}\right)$, $\eta(=0.000958 \mathrm{~Pa} \cdot \mathrm{s})$ is the coefficient of viscosity at $22^{\circ} \mathrm{C}, S_{\mathrm{m}}\left(\mathrm{m}^{2} / \mathrm{kg}\right)$ is the specific surface area per unit mass of particles, $\rho_{\mathrm{s}}\left(\mathrm{kg} / \mathrm{m}^{3}\right.$; using equation 1$)$ is the particle density and $e\left(\rho_{\mathrm{s}} / \rho_{\mathrm{d}}-1, \rho_{\mathrm{d}}=1400 \mathrm{~kg} / \mathrm{m}^{3}\right)$ is the void ratio. The dimensionless shape constant $C=0.2$ gives the best fit with experimental results (Carman, 1973).

In this study, the specific surface areas $\left(S_{\mathrm{m}}\right)$ of bentonite-sand-clay mineral mixtures were calculated according to mixed NSAP replacement ratio to bentonite $(\alpha)$ using equation 5 (Komine \& Ogata, 1999b):

$$
S_{\mathrm{m}}=\frac{S_{\mathrm{B}} \rho_{\mathrm{B}} V_{\mathrm{B}}+S_{\mathrm{N}} \rho_{\mathrm{N}} V_{\mathrm{N}}+S_{\mathrm{S}} \rho_{\mathrm{S}} V_{\mathrm{S}}}{\rho_{\mathrm{B}} V_{\mathrm{B}}+\rho_{\mathrm{N}} V_{\mathrm{N}}+\rho_{\mathrm{S}} V_{\mathrm{S}}}
$$

where $S$ is the specific surface area per unit mass, $\rho$ is the particle density, $V$ is the volume of the component and

TABLE 5. Hydraulic conductivities $\left(k, k_{\mathrm{KC}}\right)$, specific surface areas $\left(S_{\mathrm{m}}\right)$ and void ratios $(e)$ of the bentonite-sand-clay mineral mixtures.

\begin{tabular}{lrlcrl}
\hline Mixed NSAP & $\alpha(\%)$ & $k(\mathrm{~m} / \mathrm{s})$ & $k_{\mathrm{KC}}(\mathrm{m} / \mathrm{s})$, equation 4 & $S_{\mathrm{m}}\left(\mathrm{m}^{2} / \mathrm{g}\right)$, equation 5 & $e$ \\
\hline \multirow{3}{*}{ Kaolinite } & 0 & $1.4 \times 10^{-12}$ & $1.6 \times 10^{-12}$ & 264.99 & 0.92 \\
& 25 & $5.4 \times 10^{-12}$ & $2.6 \times 10^{-12}$ & 205.64 & 0.90 \\
& 50 & $1.9 \times 10^{-11}$ & $5.1 \times 10^{-12}$ & 146.28 & 0.89 \\
\multirow{4}{*}{ Mica } & 75 & $6.9 \times 10^{-11}$ & $1.4 \times 10^{-11}$ & 86.93 & 0.87 \\
& 100 & $6.0 \times 10^{-10}$ & $1.4 \times 10^{-10}$ & 27.57 & 0.86 \\
& 25 & $6.2 \times 10^{-12}$ & $3.0 \times 10^{-12}$ & 199.58 & 0.94 \\
& 50 & $6.4 \times 10^{-11}$ & $6.9 \times 10^{-12}$ & 134.16 & 0.97 \\
Chlorite & 75 & $4.8 \times 10^{-10}$ & $2.7 \times 10^{-11}$ & 68.75 & 0.99 \\
& 100 & $3.6 \times 10^{-8}$ & $1.2 \times 10^{-8}$ & 3.33 & 1.02 \\
& 25 & $4.0 \times 10^{-12}$ & $3.0 \times 10^{-12}$ & 199.64 & 0.94 \\
& 50 & $1.3 \times 10^{-11}$ & $6.7 \times 10^{-12}$ & 134.28 & 0.95 \\
& 75 & $9.2 \times 10^{-11}$ & $2.6 \times 10^{-11}$ & 68.93 & 0.97 \\
& 100 & $9.4 \times 10^{-8}$ & $1.0 \times 10^{-8}$ & 3.57 & 0.99 \\
\hline
\end{tabular}


the subscripts $\mathrm{m}, \mathrm{B}, \mathrm{N}$ and $\mathrm{S}$ represent bentonite-sandclay mineral mixtures, bentonite, mixed NSAPs and silicate sand, respectively. This equation shows the $S_{\mathrm{m}}$ changes due to differences in the volume of the component (i.e. $\alpha$ ). Therefore, the calculated specific surface area $\left(S_{\mathrm{m}}\right.$; Table 5) changes depending on the difference in mixed NSAP type and $\alpha$. When using $\mathrm{N}_{2}$ gas adsorption, only the outer surface area of montmorillonite may be determined. As water also enters the interlayer region, the specific surface area of the bentonite was calculated using equation 6 (Komine \& Ogata, 1994, 1999b):

$$
S_{\mathrm{B}}=\frac{C_{\mathrm{M}}}{100} S_{\mathrm{M}}+\left(1-\frac{C_{\mathrm{M}}}{100}\right) S_{\text {other }}
$$

where $S_{\mathrm{B}}$ is the specific surface area per unit mass of bentonite $\left(=388.8 \mathrm{~m}^{2} / \mathrm{g}\right), C_{\mathrm{M}}$ is the montmorillonite content by percentage of weight $(48 \%$; Komine \& Ogata, 1999b), $S_{\mathrm{M}}$ is the specific surface area of montmorillonite in bentonite $\left(=810 \mathrm{~m}^{2} / \mathrm{g}\right.$; Komine \& Ogata, 1999b) and $S_{\text {other }}$ is the specific surface area of component minerals, excluding montmorillonite, in bentonite. $S_{\text {other }}$ (i.e. $\sim 52 \%$ ) is composed mainly of quartz, feldspars and carbonates. The specific surface areas of these minerals are considered to be very small, as represented by silica sand in Table 3. The assumed value of $<1 \mathrm{~m}^{2} / \mathrm{g}$ is consistent with Komine \& Ogata (1999b). The calculated specific surface area was substituted into equation 4 to calculate hydraulic conductivity $k_{\mathrm{KC}}$ and to compare it with the experimental value $k$ (Table 5).

Table 5 and Fig. 9 show the hydraulic conductivities $\left(k, k_{\mathrm{KC}}\right)$, specific surface areas and void ratios of the bentonite-sand-clay mineral mixtures. The specific surface area decreased with increasing mixed NSAP replacement ratio. The particle density of kaolinite was less than that of bentonite. Therefore, the void ratios excluding kaolinite increased with mixed NSAP replacement ratio. For $\alpha=75 \%$ and $100 \%$, the $k_{\mathrm{KC}}$ hydraulic conductivity values differed from the experimental $k$ values by about one digit. This problem should be addressed in the future. On the other hand, for $\alpha=0 \%$ and $25 \%$, the $k_{\mathrm{KC}}$ and $k$ values were similar. These results suggest that the hydraulic conductivity may be estimated according to the mixed NSAP replacement ratio (i.e. degree of alteration) when the proportion of clay minerals formed by alteration is small. These data provide a basis for evaluating the hydraulic conductivity of bentonitesand mixtures with their alteration products in clay radioactive waste-disposal systems.

\section{CONCLUSIONS}

To clarify the effects of clay mineral type and content, bentonite-sand-clay mineral mixtures and clay mineral specimens were subjected to swelling-pressure and permeability tests. These experiments produced the following results:

(1) Swelling pressure and hydraulic conductivity differed according to clay-mineral type. In particular, the hydraulic conductivity of kaolinite, which is considered to have formed by the alteration of bentonite, and those of mica and chlorite were approximately three to five orders of magnitude greater than the hydraulic conductivity of bentonite. Thus, alteration probably increases hydraulic conductivity. (a)

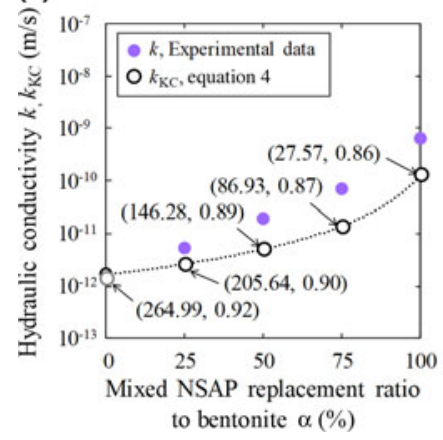

(b)

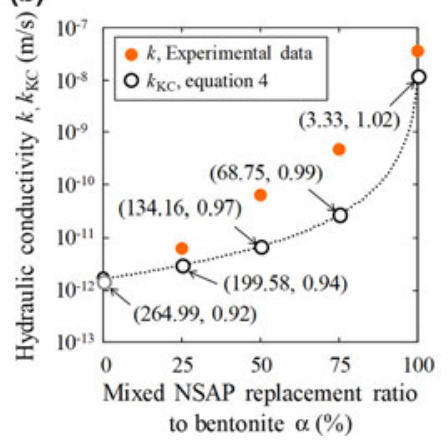

(c)

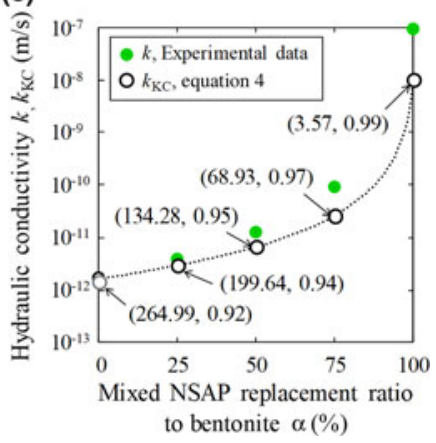

FIG. 9. Comparison between hydraulic conductivities $\left(k, k_{\mathrm{KC}}\right)$ : (a) kaolinite, (b) mica and (c) chlorite mixtures. The numerical values $\left(S_{\mathrm{m}}, e\right)$ in parts (a), (b) and (c) are the specific surface area $\left(\mathrm{m}^{2} / \mathrm{g}\right)$ based on equation 5 and the void ratio, respectively. 
(2) The swelling pressure of bentonite-sand-clay mineral mixtures decreased with increasing mixed NSAP replacement ratio, without major difference in the various mixed NSAP types. The hydraulic conductivity of bentonitesand-clay mineral mixtures increased with the mixed NSAP replacement ratio. These findings suggest that an increase in clay minerals due to alteration increases hydraulic conductivity.

(3) The hydraulic conductivity values were similar to those calculated using the Kozeny-Carman equation and specific surface area. These results suggest that hydraulic conductivity may be estimated from the clay-mineral content (i.e. degree of alteration).

Our data provide a basis for the evaluation of the swelling characteristics and permeability of engineered barriers and backfills for the geological disposal of radioactive waste. The relationship between the claymineral structures or the interlayer bonding force and hydraulic conductivity will be clarified in future studies. Such research requires an accumulation of data on the swelling pressures and hydraulic conductivities of a large number of bentonite-sand-clay mineral mixtures and clay mineral samples.

\section{ACKNOWLEDGEMENTS}

This work was partly supported by Grants-in-Aid for Scientific Research 'KAKENHI' (grant number 16K21174) of the Japanese Society for the Promotion of Sciences (JSPS). The support is gratefully acknowledged. The authors thank Mr Sumi K. and Mr Otsuki R. from Tottori University for their assistance with the experiments. The authors also thank two reviewers for their helpful comments and advice.

\section{REFERENCES}

Achari G., Joshi R.C., Bentley L.R. \& Chatterji S. (1999) Prediction of the hydraulic conductivity of clays using the electric double layer theory. Canadian Geotechnical Journal, 36, 783-792.

Carman P.C. (1937) Fluid flow through a granular bed. Transactions of the Institution of Chemical Engineers, 15, 150-156.

Chen B., Guo J. \& Zhang H. (2016) Alteration of compacted GMZ bentonite by infiltration of alkaline solution. Clay Minerals, 51, 237-247.
Cho W.J., Lee J.O. \& Chun K.S. (1999) The temperature effects on hydraulic conductivity of compacted bentonite. Applied Clay Science, 14, 47-58.

Cuisinier O., Masrouri F., Pelletier M., Villieras F. \& Mosser-Ruck R. (2008) Microstructure of a compacted soil submitted to an alkaline PLUME. Applied Clay Science, 40, 159-170.

Holland H.J. \& Murtagh M.J. (2000) An XRD morphology index for talcs: the effect of particle size and morphology on the specific surface area. Advances in X-ray Analysis, 42, 421-428.

Inoue A., Kohyama N., Kitagawa R. \& Watanabe T. (1987) Chemical and morphological evidence for the conversion of smectite to illite. Clays and Clay Minerals, 35, 111-120.

Ishii T., Yahagi R., Owada H., Kobayashi I., Takazawa M., Yamaguchi K., Takayama Y., Tsurumi S. \& Iizuka A. (2013) Coupled chemical-hydraulic-mechanical modelling of long-term alteration of bentonite. Clay Minerals, 48, 331-341.

Ishikawa H., Shibata H. \& Fujita T. (1994) Simulation of the thermal transformation of smectite to illite as the buffer material of radioactive waste disposal. Journal of the Clay Science Society of Japan, 34, 149-156 (in Japanese).

Ito M., Okamoto M., Shibata M., Sasaki Y., Danhara T., Suzuki K. \& Watanabe T. (1993) Mineral Composition Analysis of Bentonite. Power Reactor and Nuclear Development Fuel Corporation, PNC TN8430 93-003 (in Japanese).

Japan Nuclear Cycle Development Institute (2000) H12: Project to Establish the Scientific and Technical Basis for HLW Disposal in Japan, Supporting Report 2, Repository Design and Engineering Technology. Second Progress Report on Research and Development for the Geological Disposal of HLW in Japan, JNC TN1410 2000-003.

Kobayashi I., Owada H., Ishii T. \& Iizuka A. (2017) Evaluation of specific surface area of bentoniteengineered barriers for Kozeny-Carman law. Soils and Foundations, 57, 683-697.

Komine H. \& Ogata N. (1994) Experimental study on swelling characteristics of compacted bentonite. Canadian Geotechnical Journal, 31, 478-490.

Komine H. \& Ogata N. (1999a) Experimental study on swelling characteristics of sand-bentonite mixture for nuclear waste disposal. Soils and Foundations, 39, 83-97.

Komine H. \& Ogata N. (1999b) Evaluation for Swelling Characteristics of Buffer and Backfill Materials for High-Level Nuclear Waste Disposal - Influence of Sand-Bentonite Content and Cation Compositions in Bentonite. Central Research Institute of Electric Power Industry Report, Abiko Research Laboratory Rep. No. U99013 (in Japanese).

Kozeny J. (1927) Ueber kapillare Leitung des Wassers im Boden. Sitzungsber. Akad. Wiss. Wien, 136, 271-306. 
Mitchell J.K. \& Soga K. (2005) Fundamentals of Soil Behavior (3rd edition). John Wiley \& Sons, Inc., Hoboken, NJ, USA.

Mollins L.H., Stewart D.I. \& Cousens T.W. (1996) Predicting the properties of bentonite-sand mixtures. Clay Minerals, 31, 243-252.

Nakamura K., Tanaka Y. \& Hironaga M. (2011) Survey on Current Status of Laboratory Test Method and Experimental Consideration for Material Containing Bentonite. Central Research Institute of Electric Power Industry Report, Civil Engineering Research Laboratory Rep. No. N10026 (in Japanese).

Nakayama S., Sakamoto Y., Yamaguchi T., Akai T., Tanaka T., Sato T. \& Iida Y. (2004) Dissolution of montmorillonite in compacted bentonite by highly alkaline aqueous solutions and diffusivity of hydroxide ions. Applied Clay Science, 27, 53-65.

Pusch R. (1999) Is Montmorillonite-Rich Clay of MX-80 Type the Ideal Buffer for Isolation of HLW? SKB Technical Report, Rep. No. SKB-TR-99-33, Stockholm.

Ren X., Zhao Y., Deng Q., Kang J., Li D. \& Wang D. (2016) A relation of hydraulic conductivity-void ratio for soils based on Kozeny-Carman equation. Engineering Geology, 213, 89-97.

Savage D., Noy D. \& Mihara M. (2002) Modelling the interaction of bentonite with hyperalkaline fluids. Applied Geochemistry, 17, 207-223.

Savage D., Walker C., Arthur R., Rochelle C., Oda C. \& Takase H. (2007) Alteration of bentonite by hyperalkaline fluids: a review of the role of secondary minerals. Physics and Chemistry of the Earth, 32, 287-297.

Sellin P. \& Leupin O.X. (2013) The use of clay as an engineered barrier in radioactive-waste management a review. Clays and Clay Minerals, 61, 477-498.

Shirazi S.M., Kazama H., Salman F.A., Othman F. \& Akib S. (2010) Permeability and swelling characteristics of bentonite. International Journal of the Physical Sciences, 5, 1647-1659.
Sivapullaiah P.V., Sridharan A. \& Stalin V.K. (2000) Hydraulic conductivity of bentonite-sand mixtures. Canadian Geotechnical Journal, 37, 406-413.

Suzuki H., Shibata M., Yamagata J., Hirose I. \& Terakado K. (1992) Characteristic Test of Buffer Material (I). Power Reactor and Nuclear Development Fuel Corporation, PNC TN8410 92-057 (in Japanese). Suzuki K., Asano H., Yahagi R., Kobayashi I., Sellin P., Svemar C. \& Holmqvist M. (2013) Experimental investigations of piping phenomena in bentonitebased buffer materials for an HLW repository. Clay Minerals, 48, 363-382.

The Clay Science Society of Japan (2009) Handbook of Clays and Clay minerals (3rd edition). Gihodo Shuppan, Tokyo, Japan (in Japanese).

Yamaguchi T., Sakamoto Y., Akai M., Takazawa M., Iida Y., Tanaka T. \& Nakayama S. (2007) Experimental and modeling study on long-term alteration of compacted bentonite with alkaline groundwater. Physics and Chemistry of the Earth, 32, 298-310.

Yamaguchi T., Sawaguchi T., Tsukada M., Kadowaki M. \& Tanaka T. (2013) Changes in hydraulic conductivity of sand-bentonite mixtures accompanied by alkaline alteration. Clay Minerals, 48, 403-410.

Yokoyama S., Nakamura K., Tanaka Y. \& Hironaga M. (2006) Review in Alteration of Bentonite under Alkaline Conditions. Central Research Institute of Electric Power Industry Report, Civil Engineering Research Laboratory Rep. No. N05042 (in Japanese).

Yokoyama S. \& Nakamura K. (2010) Alteration Behavior of Bentonite Barrier of Radioactive Waste Disposal by Alkaline Solutions - Part 1: Permeability Change of Compacted Bentonite Immersed in Alkaline Solutions. Central Research Institute of Electric Power Industry Report, Civil Engineering Research Laboratory Rep. No. N09015 (in Japanese). 